\title{
Philosophy Education: In Pursuit of a Life
}

\author{
Vefa TAŞDELEN*
}

\begin{abstract}
Philosophy, with its quests, and responses given for these quests, reflects multiplicity and antinomial irrelevances rather than totality and relevance in itself. To draw on the premises of various philosophers, it has no direct correlative with the daily life, and it is hailed as an activity starting from the point which diverts from the daily life, and delving into the territories to explore the essence of the things. Fundamental questions to be asked in this manuscript can be articulated as thus: Can there be the teaching of an activity lacking organized knowledge and having no answers to its questions? Is it an occupation which can be operated through some educational criteria? As a form of education, what sorts of behavioural changes can philosophy education aim in a person? Furthermore, are the questions of philosophy or the answers to be instructed? If the answers are to be instructed, whose would these be? In this manuscript, it has been stated that there can be an ample ground for philosophy education through the contribution of such an education to build up an adequate correspondence with philosophy in the life of an individual, thereby constituting a philosophical life. This process has been called as a hermeneutical process in the manuscript.
\end{abstract}

Key Words: Philosophy, philosophy education, correlative of philosophy, philosophizing, occupational education, life, hermeneutic.

\footnotetext{
* Asist. Prof. Dr., Yüzüncü Yıl University, Department of Philosophy.
} 


\section{SUMMARY}

Philosophy is an activity related with the questions about the very existence of an individual and the replies based on and explored in such an existence rather than an activity to be instructed, shown or transferred by one person to the other. Within this context, philosophy can be considered as having a correlative in us. It gains a concrete meaning so long as such a correlative exists in us. Meaninglessness will come to the fore, in case such a correlative does not exist. Philosophy education is an activity through which philosophy builds up its correlative in a person. Thus, it would be much more tempting to say that philosophy is an activity which builds up its correlative in the individual through its education. Building-up of such a correlative first of all presupposes the questions to be possessed by us and to be originated from the very existence of a person himself. While constituting such a bonding with philosophy, we direct quests and queries based not upon an external source, but explored in our existential being and springing from our curiosity. Our aims and objectives to direct such quests are compiled not to the knowledge to be acquired about a profession but to the love of wisdom cherished towards knowledge. In order, for those quests, to be possessed by us, they should either be derived from our existence or they should acquire some status in such an existence after they come to us through learning externally. This presupposition which can found the principles of philosophy education may pave the way for a philosophical life in us; such a life is the correlative of philosophy in a person. A philosophy student is a person who unravels his existence to philosophy and philosophy to his existence after gaining status for being a student to the love of wisdom. Thus can we render philosophy a non-occupational status and designate a meaning for philosophy within the context of leading a life. This is the objective of philosophy education. In order, for philosophy, to take the from of a living experience, it is imperative that the student possess some problematic. Philosophy can be rendered a living experience only through a problematic possessed by the person and internalized in himself. This is a kind of quest which we directed to ourselves and which we built up its correlative with our writings and narratives. If a philosophy education is to be institutionalized, it should start from possession of such a quest by the student.

The correlative of philosophy can be constituted through the process of philosophizing as an important sphere in which the philosophic knowledge is rendered useful when asking the question of what use can we make of philosophy? We can get an appropriate answer which is most suitable and realistic for the nature of philosophy: It will be useful for philosophizing. Therefore, the process of philosophizing, consisting the learning of philosophy goes further: It means any possible contribution to be made to philosophy by these questions and answers. Only when we initiate the 
process and activity of philosophizing can philosophy be rendered meaningful and operational to us. Is there, then, a possibility of learning philosophizing without learning philosophy itself. This is like the case of a person who operates a surgical patient without having any medical knowledge necessary for doing such an operation. Philosophy education primes philosophizing. In order to philosophize, one should learn philosophy. Philosophical knowledge is immanent in the activity of philosophizing. Thus, in the acquisition of philosophizing, there exist both the learning of philosophy and philosophizing, that is to say, there exists philosophy education. Thus, this is one of the reasons of the impossibility of the teaching of philosophy as a science in the real terms. In reality, there can be found no readily truths to be instructed in philosophy, but there are ones which can be attainable, and they are for those persons who are to attain, no for those who could not.

Since no quest of philosophy can attain absolute solutions and answers, philosophy emerges as an object of contemplation not as an object of teaching. So, its teaching can only be useful in search of novel answers and solutions in an everchanging and evolving intellectual process, thereby paving the way for a more adequate and beneficial education of philosophy. If philosophy education is not committed to an occupation, a job or a career, what aims and objectives might it have? We can give an answer to this question by saying that it aims to constitute a life. Philosophy question is directed to the constitution of a philosophical life and such a life is the most important ground for philosophy education. Presupposition of a rational life by philosophy does not necessarily mean the repulsion of sentiments and intuitions. No matter what qualities the experienced life possesses, it is the visualization of every sphere of life through the mind's eye. This insight constitutes the principles of philosophical life. Thus, philosophership/philosophy is not an occupation but a way of life. This life, which is moulded with language, history, culture and civilization, is an apprehending process and a regeneration activity and has a hermeneutical quality. 


\title{
Felsefe Eğitimi: Bir Yaşantının Peşinde
}

\author{
Vefa TAŞDELEN*
}

ÖZ: Felsefe, soruları ve bu sorulara verdiği cevaplarla kendi içinde bir birlik ve tutarlılık değil, aksine çokluk ve tutarsızlık gösterir. Gündelik hayatta doğrudan bir karşılığı olmadığı gibi, kimi filozofların deyişlerine bakacak olursak, gündelik hayatın bittiği yerde başlayan, gündelik olmayanı araştıran, şeylerin özüne ve esasına ulaşmayı amaçlayan bir etkinlik durumundadır. Bu makalede sorulan temel sorular şunlardır: Düzenli bilgiden yoksun, soruları bile çözümsüz olan bir "etkinliğin", bir "bilgelik sevgisinin" öğretimi yapılabilir mi? Felsefe bir bilim midir ki eğitimi yapılabilsin? Bir meslek midir ki öğretimi olsun? Felsefe eğitimi, bir eğitim biçimi olarak, kişide hangi davranış değişikliklerini amaçlar? Dahası, felsefenin soruları mı ögretilmeli, yoksa cevapları mı? Eğer cevapları öğretilecekse, kimin, hangi filozofun cevapları öğretilmeli? Bu ve benzeri sorulardan hareket eden bu makale, felsefe eğitiminin temel sorunları üzerinden giderek bu eğitim biçiminin olanağını, bir "bilim" ve "meslek öğretimi”" olarak yapılmasında değil, kişide felsefi merakı uyandırmasında, felsefeyi varoluşla ilişkilendirmesinde, bu şekilde felsefi yaşantıyı başlatmasında ve geliștirmesinde bulur. Bu eğitim sürecini de, felsefi metinlerle iletişime geçme, onları okuma, anlama, yorumlama ve ifade etme açısından hermeneutik bir süreç olarak görür; felsefe öğrenimini "felsefe yapmanın öğrenilmesi", felsefe öğretimini de "felsefe yapmanın öğretilmesi" olarak öne çıkarır. Böylece, felsefe eğitimi, felsefeyi bireyde "anlamı" ve "karşıllğı olan" bir etkinlik haline getirir. Bu eğitim ve öğretim yaşantısı, makale içinde, "felsefenin kişide karşılığını kurma süreci" olarak adlandırılır.

*Yrd. Doç. Dr., Yüzüncü Y1l Üniversitesi Felsefe Bölümü. 
$\mathrm{Bu}$ anlamda felsefe eğitimi, belli zaman ve mekanla sinırlı resmi bir öğretim süreci olmanın dışına taşar, kişide anlamı ve karşılığı olan içtenlikli bir yaşantı haline gelir.

Anahtar Sözcükler: Felsefe, felsefe eğitimi, felsefenin karşllığı, felsefe yapma, meslek eğitimi, yaşantı, hermeneutik.

\section{GİRIŞ}

Bugün dünyanın pek çok ülkesinde felsefe bölümleri vardır. Bunun yanında, farklı birim ve alanlarda da felsefe dersleri okutulmaktadır. $\mathrm{Bu}$ durum, insanların felsefeyi öğrenmeyi ve öğretmeyi istediklerini gösterir. Aslına bakılırsa, felsefe eğitiminin geçmişi, felsefe kadar eskidir. Sözgelimi, Sokrates'in çarşıda pazarda bir gönüllüsüne rastladı $\mathrm{m}$, ayaküstü de olsa başlayıverdiği diyalogları, felsefe eğitiminin en canlı ve en görkemli örnekleridir. Bu örneklerde yalnız felsefeden söz edilmez, felsefe ile birlikte geometriden, tarihten, politikadan, hukuktan, şiirden, siyasetten, ahlaktan, sanattan da söz edilir. Öyle ki, bugün bile tartışılmakta olan kimi etik, politik, toplumsal ve eğitimsel sorunların temelini, o gün yapılan tartışmalarda bulabiliriz (Rusk-Scotland, 7). Felsefe, nasıl ki tüm bilimlerin kökenini oluşturuyorsa, felsefe eğitiminin de işte öylece tüm bilimlerin eğitiminin kökenini oluşturduğu söylenebilir. Bugün, bilimlerin bir bir kendisinden bağımsızlaştığı bir felsefenin eğitim ve öğretiminin nasıl olması gerektiği, kendi başına bir sorundur. Felsefe eğitimi kapsamında neredeyse ilk akla gelebilecek sorular, bu eğitim biçiminin olanağına ilişkindir: Bir felsefe eğitiminin gerekçeleri neler olabilir? Düzenli bilgiden yoksun, soruları bile çözümsüz olan -Wittgenstein'ın deyişi ile- bir "etkinliğin" (tätligkeit) öğretimi olabilir mi? Felsefe bir bilim midir ki eğitimi yapılabilsin? Bir meslek midir ki öğretimi olsun? Felsefi eğitim, bir eğitim biçimi olarak kişide hangi davranış değişikliklerini amaçlar? Dahası, felsefenin soruları $\mathrm{m} 1$ öğretilmeli, yoksa cevapları mı? Ĕ̆er cevapları öğretilecekse, kimin, hangi filozofun cevapları öğretilmeli?

$\mathrm{Bu}$ çalışma, felsefe eğitiminin gerekçesini, bu eğitimin kişide felsefenin karşıllı̆̆ını kurmasında, felsefi metinlerle ilgi içinde kendi varoluşundaki felsefeyi keşfetmesinde, bu şekilde felsefi yaşantıyı oluşturmasında görür. Felsefe eğitiminin felsefi yaşantıyı oluşturması, her eğitim öğretim etkinliğinin bir yaşantı oluşturmaya yönelik gerçekleştiği hususu ile de örtüşür. Felsefe eğitiminin, kişide felsefenin karşılığını kurarak bir yaşantı oluşturmas1, hermeneutik bir süreçtir. Hermeneutiğin felsefe eğitimine katkısı, kişinin kendi anlama ve ifade etme yetisini etkin hale getirmesi konusunda yaptığı vurgu üzerinde gerçekleşir. $\mathrm{Bu}$ da kendi dilini kullanmakla, kendi varoluş koşullarını anlamaya katmakla, kendi sorularını sormakla ve kendi cevaplarını vermekle gerçekleşir. Bu anlamda felsefe 
yapmak, bir dünya kurmaktır. Ama bu söylenenler kabul edilirse, tarihsel ve kültürel koşullarıyla ancak bir dünyası olanların, hermeneutik bir daire içinde bulunanların felsefe yapabilecekleri sonucu da ortaya çıkar. Bu nedenle felsefe yapmak, hermeneutik bir etkinliktir. Felsefe metinlerini anlamak, felsefenin eğitimini ve öğretimini görmek de bu hermeneutik etkinliğe dahidir.

\section{Felsefenin Kişideki Karşılığı}

Felsefenin öğretilemeyeceğine ilişkin bazı görüşler vardır. Bu görüşler temellerini, felsefenin bir bilim, felsefeciliğin de bir meslek olmayışında bulurlar. Sözgelimi, Husserl'e göre, felsefe, baştan beri, kendisinin en yüksek teorik sorulara cevap verebilecek, etik-dinsel yönden saf akıl normlarına göre düzenlenmiş bir hayatı olanaklı kılacak bir bilgi olduğunu savunmuştur. Bu sav, bazen güç kazanmış, bazen zayıflamış, fakat hiçbir zaman elden bırakılmamıştır. Bu böyle olmakla birlikte, değil kesinlik taşıyan bir bilim olmayı, yetkin olmayan bir bilim sınıflaması içinde bile yer alamaz. Felsefe öyle bir yolda ilerlemiştir ki, "gelişmesinin hiçbir çağında, kesin bir bilim olma savına yeterli olamamıştır. Hatta problemlerinin özel anlamı konusunda bile bilimsel bir açıklığa kavuşamamıştır" (Husserl, 33). Wittgenstein da, felsefenin, bir bilim ve öğreti değil, yalnızca bir "etkinlik" (tätligkeit) olduğu görüşündedir (Wittgenstein, 2003: 59). Bunun haklı bir gerekçesi vardır. Zira Jaspers'in de işaret ettiği gibi, felsefe bir bilim veya öğretim dizgesi durumunda saydamlaşırsa, ortadan kalkar (Jaspers, 200). Bu nedenle de, "Felsefe öğretilemez; çünkü burada böyle objektif olarak kavranmış ve temellendirilmiş görüşler yoktur. Bunun anlamı şudur: Burada kavramlarla kesin bir şekilde sınırlandırılmış ve anlamları tümden aydınlanmış problemler, yöntemler ve teoriler yoktur." Husserl, sözünü şu şekilde sürdürür: "Kant, felsefenin değil, felsefe yapmanın öğrenilebileceğini söylemeyi severdi. Bu, felsefenin, bilimsellikten yoksun olduğunu itiraf etmekten başka nedir?” (Husserl, 34).

Felsefenin öğretilemeyeceği, aynı zamanda onun bir eğitiminin de olamayacağ 1 anlamına mı gelir? Eğer öğretim bize bir bilimi ve mesleği öğretecekse, doğrudur, o zaman bu niteliklerden yoksun olduğu için felsefe öğretiminin olamayacağını söyleyebiliriz. Öğretimdeki bu "teknik" özellik, eğitimin geniş tanımında farklı açılımlara kavuşur. Gerçekten de eğitimi bir tutum ve yaşantı kazanmak anlamında düşünecek olursak, o zaman bir felsefe eğitiminden de söz edebiliriz. Felsefe eğitimini olanaklı kılacak bu yaklaşımı şu şekilde açıklayabiliriz: Hayret, merak ve felsefenin doğasında olan bilmeye karşı duyulan sevgi gibi insan varlı̆̆ında içkin halde bulunan temel duygular, felsefenin insan doğasının dışında değil, onun içinde, varoluşuyla temelden bağıntılı bir etkinlik olduğunu gösterirler. Felsefe, bir kişinin başka bir kişiye öğretebileceği, gösterebileceği, aktarabileceği bir bilgi değil, olsa olsa kişinin kendi varoluşundan türettiği soru ve yanıtlarla 
yine kendi varlığında keşfedeceği bir etkinliktir. Çünkü felsefe, bizde karşıllğ̆ olan şeydir. Bizde bir karşılık bulduğu sürece somutluk kazanır, bir anlama gelir. Karşıllı bulmadığı sürece, bizim için yabancılaşır, bir anlam ifade etmez. Bu açıdan, felsefe eğitimi, felsefenin kişideki karşılığını kurma etkinliğidir, denilebilir.

Peki, "felsefenin karşılığını oluşturma" nedir? Felsefenin karşılığı nasıl oluşur? "Karșılık olușturma", öncelikle, sorduğumuz soruların bize ait olması, kendi varlığımızdan türemiş olması anlamına gelir. Felsefenin kendimizdeki karşılığını oluştururken, bir kitapta yazan soruyu değil, kendi varlığımızda keşfettiğimiz, kendi hayretimizin ve merakımızın ürünü olan bir soruyu sorarız. Bu soruyu sormaktaki amacımız, bir mesleğe ilişkin bilgiyi kazanmak değil, bilmeye duyduğumuz sevgidir. Bu nedenle soruyu bir kitaba, sözgelimi bir ansiklopediye, bir uzmana değil, öncelikle kendimize sorarız. Çünkü felsefi yanıt başkasından değil, öncelikle soruyu sorandan gelmelidir. Çünkü o, başkasının cevap vermesi için değil, bizzat cevaplamak için sorar soruyu, bu nedenle başkasına değil, öncelikle kendine sorar. Felsefe, başkalarının soru ve cevapları ile değil, kendi soru ve cevaplarımızla kımıldar içimizde. Soruların kendi sorularımız olabilmeleri için, ya kendi varoluşumuz içinden çıkmış, ya da öğrenme yoluyla ona dışarıdan gelerek bu varoluş içinde bir konum kazanmış olmaları gerekir. Felsefe eğitimini gerekçelendirebilecek bu husus, bizde felsefi yaşantıyı oluşturur. Felsefenin hayatla arasına bir duvar çekmek ve onları birbirinden ayırmak mümkün değildir. Bu nedenle felsefe eğitimi, felsefeyi hayattan ayırmaya değil, öncelikle onunla birleştirmeye çalışır. Felsefe eğitimi, yaşamla felsefe arasındaki sınırları kaldıran, ilerledikçe felsefenin yaşam, yaşamın felsefe olduğu bir etkinlik alanıdır. Bu katılım, her meslek için az çok söz konusu olsa da, felsefe öğrencisi, bir bilgelik sevgisi öğrencisi olarak işe başlarken varoluşunu felsefeye, felsefeyi de varoluşuna açan kişidir. Böylece felsefe bir meslek olmaktan çıkar, bir yaşam sürme işi haline gelir. İşte bu, felsefe eğitiminin amacıdır. Felsefe eğitimi, felsefeyi bir yaşantı haline getirme sanatıdır.

Felsefenin bir yaşantı haline gelmesi için öncelikle öğrencinin sorun sahibi olması gerekir. Felsefe, ancak kişiye ait bir sorun, kişide içselleşmiş bir sorun ile yaşantı haline gelir. Felsefi olarak düşünebilmek ve felsefenin ortamına girebilmek için, bizi tutan ve yakamızı bırakmayan sorularımızın olması gerekir. Camus, düşünmenin "için için yenmeye başlanmak" olduğunu söyler (Camus, 14). Düşünürken bir dünyayı seyrederiz, bir dünya kurarız. Düşünme bizi "ilgilendiren” bir şeydir. Düşünürken kendimizle düşündügümüz şey arasında "ilgi” kurarız. Soruları işlerken, onları önümüze koyup bir sorunsala dönüştürürken, sorular da bizi işler. Sorun, kendimize sorduğumuz şeydir, yazdıklarımızın ve söylediklerimizin bizde karşılık bulmasıdır. Sorunsuz felsefe ve felsefe eğitimi, temelden yoksun, olsa olsa 
karşıllı̆ 1 olmayan bir etkinlik olacaktır. Eğer bir felsefe eğitimi olacaksa, bu her şeyden önce, soruların ve sorunların öğrenciye kazandırılması ve özümsetilmesi ile başlayacaktır. Sorunlarımızı işlerken, kendimizi geliştirirken, yaptığımız işin sağlamasını, onların bizdeki karşılıklarına bakarak yapabiliriz. Karşılığı olmayan söylemler, sağlaması yapılamayan çözümlemelerdir. Felsefe eğitiminde de, "Kendi yaşamımızdan kaynaklanan felsefe yapma yolunun denenmesi" en sahici tutum olacaktır (İnam, 6). Kendi yaşamımızdan kaynaklanmayan, bu temel üzerinde karşıllk bulmayan bir felsefe etkinliği, yalnızca felsefenin içinden çıktığı tarih, dil ve kültür ortaklarına değil, etkinliği gerçekleştiren kişilere bile bir şey söylemeyecektir.

\section{Felsefe Eğitimi, Felsefe Yapmanın Eğitimi.}

Felsefe eğitimi söz konusu olduğunda, felsefenin mi yoksa felsefe yapmanın mı öğrenileceği/öğretileceği önem kazanır. Kant'ın dile getirdiği, "Size felsefeyi değil, felsefe yapmayı öğretiyorum" sözü, haklı olarak bu konudaki bir sorunu da gündeme taşır. Jaspers'e göre, felsefe öğrenmek, tıpk1 Kant'ta olduğu gibi "felsefe yapmaya katılma" ve "felsefe yapmayı öğrenme"dir. Felsefenin tam olarak bir bilim gibi öğretiminin yapılamayacağı şuradan bellidir ki, onun genel geçer doğruları, kesin sonuçları ve felsefe metinleri dışında nesnesi yoktur. "Felsefe öğrenmek, öğretenin düşünce akımına, araştırma, inceleme yöntemlerine katılmak demektir; bu da felsefe yapmaya katılmaktır. Burada ögrenilen Kant'ın söyleyişiyle, felsefe değil, felsefe yapmaktır" (Jaspers, 195).

Öyle görünüyor ki, felsefe yapmak, felsefe bilgisinin işe yaradığ önemli alanlardan biridir. "Felsefe ne işe yarar" diye sorulduğunda, "felsefe yapmaya yarar" cevabı, en gerçekçi ve felsefenin doğasına en uygun cevap olacaktır. Eğer felsefe yapmayacaksak, felsefeyi kendi yaşantımıza katmayacaksak, olaylar ve olgular karşısında eleştirel bir tutum takınmayacaksak, yeryüzündeki varlığımızın anlamını sorgulamayacaksak, felsefe bilmenin, felsefe öğrenmenin ne gibi bir anlamı olabilir? Felsefi bilgi yaşantımıza değmeden, kendi dünyamızda karşılık bulmadan, salt kitaptaki bilgi olarak kalıyorsa, bu durumda felsefe yapmanın malzemesi olmaktan çıkar ve bir genel kültür bilgisi haline gelir. Felsefe yapmayı öğrenmeden gerçek anlamda felsefeyi de öğrenemeyiz. Felsefeyi öğrenmek, özgül anlamında, felsefe yapmayı öğrenmektir. Çünkü o bir soru sorar ve sorusuna cevap arar. Felsefe öğrenmek başkalarının cevabını öğrenmektir, felsefe yapmak kendi cevabını da vermektir. Dolayısıyla, felsefe yapmak, felsefeyi öğrenmeyi içerdiği gibi, daha da ileri gider: Kendi sorusu ve cevabıyla felsefeye katkı sağlamayı da ifade eder. Bu açıdan, kendi başına felsefenin bir öğretimi, gerçek anlamda mümkün değildir. Bunun çeşitli nedenleri vardır: Öncelikle, felsefenin devasa birikimi, onun kuşatıcı bir şekilde öğrenilebilirliğini engeller. Gerçekten de, felsefe başlangıcından günümüze, 
derin ve geniş bir deneyim geçirmiştir ve bunun kuşatıcı bilgisine sahip olmak, hele hele bir felsefe öğrencisi için neredeyse imkânsızdır. Onu bir meslek olarak seçip ömrünü bu yolda harcayan kişiler için de aynı durum söz konusudur. Hangi felsefeyi öğreteceğiz? Hangi filozofları okutacağız veya okuyacağız? Bütün bunlar da, felsefi bir tutumu gerekli kılar. Şu halde, esasta, felsefe öğrenmek, sıradan öğrenmenin anlamını aşarak felsefe yapmaya dönüşür. Her felsefe öğrenme eyleminde, doğrudan felsefenin içine dalma, felsefeye ve felsefenin geçmişine kavrayıcı bir bakış atma söz konusudur. Felsefenin değil de, felsefe yapmanın öğretilmesi bu zemin üzerinde gerekçesine kavuşur. $\mathrm{Bu}$, felsefenin tam olarak öğrenilemeyeceği gerçeğini de ifade eder. Zira felsefe birkaç kitap, bir kaç filozof değildir. Ancak felsefe yapmaya başladığımızda, felsefe bilgisi bizim için anlamlı ve işlevsel hale gelir.

"Felsefe yapmanın öğretilmesi” deyişi, aşırı bir iddia gibi görülebilir. $\mathrm{Ne}$ var ki, felsefe yapmanın öğretilmesi, felsefenin öğretilmesi iddiası karşısında, tıpkı "philosophos" ve "sophos" ayırımında olduğu gibi, daha mütevazı bir tutumu ifade eder: "Sophos" bilge olan kișidir, "philosophos" ise bilge olduğunu değil, ancak bilgeliği seven biri olduğunu söyleyen kişidir. Bunun gibi felsefe yapmanın öğretilmesi iddiası da, kendi içindeki çokluğu, çeşitliliği, öznelliği, kesinsizliği ve belirsizliği ile devasa felsefe birikimini öğretme iddiasından daha büyük bir iddia değildir. Felsefe yapmanın öğretilmesi, bir takım kuram ve kavramların akademik bir titizlikle öğrenciye yüklenilmesinden ziyade, felsefi tutumu yaşantıya mal etmek, felsefeyi yaşama katmak, felsefeyi ve felsefi sorunları kendi varoluşunda keşfetmek gibi bir süreci ifade eder. Çünkü "felsefe yapmayı öğrenmek" hem zihinsel bir öğrenme işlemini, hem de bir işi, yani felsefe yapmayı başarabilmek gibi bir anlamı ifade eder. Burada haklı olarak şöyle bir soru sorulabilir: Felsefe ögrenilmeden, felsefe yapmak öğrenilebilir mi? $\mathrm{Bu}$, bir insanın, tıp bilgisine sahip olmadan ameliyat yapmasına benzer. Felsefe eğitimi, felsefe yapmayı önceler. Felsefe yapmak için, öncelikle felsefeyi öğrenmek gerekir. Felsefe bilgisi, felsefe yapma eyleminde içkin halde bulunur. Felsefe yapma edimi, hem felsefeyi, hem de felsefe eğitimini içerir.

Felsefe eğitiminin en görkemli örnekleri olarak görebileceğimiz sokratik diyalogların pek çoğu, onca kavramsallaştırmadan, çözümlemeden ve uslamlamadan sonra kesin bir sonuçla "şudur" diye bitmez, bir belirsizlikle, bir çözümsüzlükle (aporía), kimi zaman ele alınan sorunun güç bir sorun olduğunun itirafı ile biter. Bu durum, yeni çözüm arayışlarına kapı aralar. Göze alabilenler, hiç bir yanıtın nihai çözüm olamayacağını bile bile sorunu kendilerince çözüme kavuşturma denemesi içine girerler. Felsefedeki çok yanıtlılığı, çok yanıtlılığın karmaşasını ortadan kaldırma yönünde girişimde bulunan herkes (bu yönde bir çaba her filozofta az ya da çok 
görülür) ancak olası yanıtlar içinden bir yanıt olarak yerini alacak, böylece çözümün değil çözümsüzlüğün beslenmesine katkıda bulunacaktır. Nihai sorulara nihai çözümler sunmayı istemek, hep bunun peşinde olmak felsefenin yazgısıdır, ama sunamamak, ya da sadece filozofların kişisel ve sınırlı bakış açılarıyla sunmak da yazgısıdır. Felsefe varlığını sorunlarını çözmede değil, çözememede, böylece kendi uğraşısı içinde onları çoğaltmada ve çeşitlendirmede bulur. Felsefenin tarihine baktığımız zaman, onun bir verilmiş cevaplar tarihi olmaktan çok, bir çözümsüz sorular tarihi olduğunu görürüz. Bu nedenle, "Felsefenin ifadesinde belirli güçlükler vardır. Bir uzman, diğer uzmanlar için biyoloji, kimya ya da tarih konusunda yazıyorsa, gönül rahatlığı içinde, genel olarak kabul görmüş bir alanı, bir konuyu ele alabilir ve konunun araştırılmasında kullanılan yöntem hususunda kabul edilmiş varsayımlardan yararlanabilir. Fakat felsefede evrensel olarak kabul edilmiş bir alan, konu ve yöntem yoktur. Felsefenin doğası ve işlevi, öteden beri bizzat kendisi için bir problemdir" (Reid, 3). Bizzat kendisi için bir problem olan felsefenin bir bilim gibi, bir meslek gibi öğretiminin gerçek anlamda mümkün olmayışının bir başka nedeni de budur.

Aslına bakılırsa cevapsız değildir felsefi sorular, çözümsüz de değildir. Ancak, bu cevaplardan ve çözümlerden hiç biri, soruyu ortadan kaldıracak denli güçlü değildir. Ne söylenirse söylensin, nasıl cevaplanırsa cevaplansın, soru yine kendisi olarak kalacaktır. Bu nedenle felsefe, sadece yolda olmak değil, yolu farklı bir ruh hali içinde, farklı bir bakış ve yaşantı ile yeni baştan yürümektir de. Felsefenin cevapları, bilimlerin verdikleri cevaplar gibi değildir. Bilimsel cevaplar soruyu önemli ölçüde bitiren cevaplardır. Artık bundan sonra yapılacak iş, bu cevapların öğretilmesidir. Bilim adamı herkes adına cevaplar soruyu. Oysa filozof, "bence" diye başlar ve yalnızca kendisi adına, kendi bakış açısına göre cevaplar. Bu cevap soruyu bitirmediği gibi yeni sorular1 da beraberinde getirir. Felsefede soruyu bitiren bir cevap olsaydı, soru yeni sorularla birlikte kendisini yineleyip çoğaltmasaydı, sadece verilen cevabın öğretilmesi söz konusu olacaktı. Felsefe öğretiminde öğretilen, filozofun "bence" diye başladığ1 görüştür. Öğrenirken "filozofa göre" olan cevabı öğreniriz. Doğal olarak bu göreceli cevap ancak filozof için geçerlidir. Filozof onu kendi adına cevapladığı için, soru başkaları için hala cevaplanmamıştır. Felsefenin hiçbir sorusu kesin çözümlere ve yanıtlara ulaşmadığından, bir öğrenim nesnesi olarak değil, bir düşünüm, bir tefekkür nesnesi olarak ortaya çıkar. Filozofun cevabı, ancak kendi cevabımızı bulabilmemiz için bir vesiledir. Bu nedenle felsefenin öğrenilmesi, felsefe yapmanın öğrenilmesidir. Onun öğrenimi ve öğretimi ancak yeni bir yanıta ve çözüme yarayabilir. Kesin bir sonuca ulaşmaksızın soruların yinelenip gitmesi, felsefenin bir hakikat arayışı olduğu gerçeğini ortadan kaldırmaz. Onun bu yazgısı, yüzlerce yıl önce Aristoteles'in dilinde şu şekilde ifade bulmuştur. "Hakikatin araştırılması bir anlamda güç, bir başka anlamda kolaydır. Bunun bir delili, hiç kimsenin tam olarak onu elde edememesi, 
ancak öte yandan insan türü olarak ondan uzak olamamamızdır" (Aristoteles, 149). Aristoteles'in bu sözleri ile felsefenin tarihsel yazgısına ulaşmamız da mümkün görünmektedir: Felsefi sorulardan, doğasında merak bulunan insan varlığı olarak uzak kalamayız. Ama bu sorulara, kendilerini ortadan kaldıracak, soru olma niteliklerini bitirecek denli kesin ve genel geçer cevaplar da veremeyiz.

Burada şöyle bir soru sorabiliriz: Felsefeyi kimin için öğreniriz? Eğer o bir meslekse, her meslek gibi başkaları için, başkalarına fayda sağlamak için, bir iş ve hizmet üretmek için öğreniriz. Dewey, meslekten, topluma yararlı olan, toplumu oluşturan bireylere hizmet sunan etkinliği anlar (Dewey, 307). Meslek eğitimi de, bizi başkalarına ulaştırmaya, onlardan hizmet almaya ve onlara hizmet vermeye hazırlayan bir eğitimdir. Felsefecilik, eğer bir meslekse, bu onun okutulup öğretilebileceği anlamına gelir. Felsefenin insanlara, toplumlara, uygarlıklara bir katkıs1, bir yararı olabilir. Ama bu katkı bir meslek adamının yaptığı, sözgelimi bir doktorun, bir kimyacının, bir eczacının yaptığı anlamda bir katk1 değildir. Felsefecilik, eğer başkalarına hizmet etmek anlamında bir meslekse, başkalarına bu yolla hizmet etmek için öğreniriz. Ama acaba felsefe ile insanlara hizmet olur mu? "Felsefe hizmeti" sözcügünün anlam ve içeriği nedir? Felsefeyi başkaları için okuyup öğrenmeye çalışmak, gerçekten felsefi bir tavır mıdır? Yoksa felsefe kendisi için okunup öğrenilen, kendisine hizmet için eğitimi yapılan bir etkinlik midir? Felsefeyi kendimiz için öğreniriz, bu eğitim biçiminin öncelikli amacı budur. Zira o bize ulaşmadan, bizden başkalarına ulaşması da mümkün değildir. Başkalarına öğretmek için felsefe öğrenmek, felsefenin kendi doğasında yoktur. Sorular, genelliği olmasına karşın, kişinin kendi varlığında keşfettiği sorulardır. Bu nedenle, kendi sorularını başkaları için yanıtlayamaz doğal olarak, öncelikle kendisi için yanıtlar. Böylece, ürettiği felsefe, filozofun kişiliği ve bireysel yaşamı ile özdeşleşir. Bu da, felsefeyi, yine felsefe yapmak için öğrendiğimiz gerçeğini doğrular. Felsefe bilgisi, öncelikle felsefe yapmaya yarar. Felsefe eğitimi, felsefenin dönüp dolaşıp yine kendisine geldiği bir eğitim biçimidir. $\mathrm{Bu}$ eğitim biçimi, insanın yeryüzündeki varlığını aydınlatma yönünde kişiyi geliştirir. Bu da felsefeden bireye, insanlığa ve topluma gelen, sonuçta yine felsefenin kendisine dönen bir hizmettir. Bu hiç de azımsanamayacak bir hizmet olduğu için, felsefe her dönemde değerli olmuş ve insanlar onun eğitimi ve öğretimi ile meşgul olmuşlardır. Çünkü o insanın yeryüzündeki varlığının anlamını sorgulayabilecek, bu konuda bilgi ve düşünce üretebilecek en önemli insan etkinliğidir. Bu anlamda, felsefe eğitimi, insanın kendisine dönük bir eğitim biçimidir. Başkalarına hizmet götürme amacı taşımadığı için, bir meslek eğitimi değildir. Kişinin kendi varoluşu merkezinde bulguladığ 1 felsefe ve felsefe eğitimi, sonuçta yine felsefenin kendisine dönen bir gelişim gösterir. $\mathrm{Bu}$ nedenle, felsefe eğitimi, salt felsefi soruların cevaplarının öğretildiği bir eğitim biçimi olmamalıdır. Böyle bir eğitim, çeşitli düşünceleri, akımları ve 
filozof görüşlerini öğretir öğretmesine, ancak bunların her birinin biricik cevap olmadığını da, farklı cevaplar karşısında her cevabın bir alternatif olduğunu da öğretir. Bunun da ötesinde, felsefe eğitimi, hazır ve öğrenilebilir cevaplarla felsefeyi bitirmez, düşünmenin bizzat kendisini teşvik eder ve onun gelişmesini ister. Kişinin kendi düşüncesini ortaya koymasına, kendi cevabını vermesine de imkan tanır. Denebilir ki, filozofların cevabı bunun için bir vesiledir. Kant'ın, "Size felsefeyi öğretmiyorum, felsefe yapmayı öğretiyorum” sözü gibi, Wittgenstein'ın şu sözü de bu bağlamda değerlendirilebilir: "Yazımın, başkalarını düşünme sıkıntısından kurtarmasını değil, eğer olanaklıysa insanın kendi düşüncelerini harekete geçirmesini istiyorum" (Wittgenstein, 1998: 8). Felsefe eğitimi, en önemli gerekçesini, soruları, verilmiş cevaplarla tüketmede değil, kişinin kendi cevabını üretebilmesine yaptığı katkıda bulur.

\section{4. Felsefe Eğitimi, Felsefi Yaşantıyı Oluşturur}

Kesinliği olmayan, doğruluğundan ve yanlışlığından söz edilemeyen görüşler, kavramlar nasıl öğretilecek, kime göre ve ne kadar öğretilecektir? Eğer bir kavram, her filozofta ayrı bir içeriğe kavuşuyorsa, filozof sayısınca tanımı ve anlamı varsa, onun öğretiminden nasıl söz edebiliriz? $\mathrm{Bu}$ anlamlardan hangisi öğretilecek, hangisinin doğruluğu vurgulanacaktır? Bütün bu görüşler öğretilmiş olsa bile, böyle bir öğrenmenin yararı ne olacaktır? Bu sorular, gerçekten felsefe öğretiminin "anlamının ne olduğu" sorusunu gündeme taşıyacaktır. Varsayalım ki, bir kişi öğretim gördüğü felsefe bölümünden tüm fillozofların tüm görüşlerini öğrenerek çıksın, bu kişi felsefeyi ve felsefe yapmayı biliyor mu olacaktır? Bu kadar bilgiyi ve kavramı ne yapacak, nerede kullanacak, onlarla hangi sorunun çözümünü gerçekleştirecektir? Bu bilgiler hayatını kolaylaştıracak, kendisini yaşamın zorlukları karşısında dirençli, kararlı, mutlu ve başarılı kılacak mıdır? Söz konusu bu kişi, bir yabancı dil eğitimi almış olsaydı, bir yabancı dilde konuşuyor, okuyor, yazıyor ve anlıyor olacaktı; tıp eğitimi alsaydı bazı hastalıkları tedavi etme becerisini kazanacaktı; teknik bir bölümü bitirseydi, bozulan bir makineyi tamir edebilecekti; fizik eğitimi alsaydı maddenin, biyoloji eğitimi alsaydı canlının yapısını inceleyebilecekti. Peki, felsefe eğitimi almış olan bir kişinin yapabileceği iş nedir? Kendisini hangi alana ilişkin sorunları çözmek için hazırlamıştır? Sonuçta, bu tür kişilerin, toplumsal hayatta ustalıkla yapabilecekleri bir iş, üretebilecekleri bir hizmet olmadığından, işsizlik sorunu ile karşılaşmaktalar. Felsefe mezunları için başlıca iş alanı, öğretmenliktir. Yalnız felsefe öğretmeni değil, zaman zaman alan dışı atamalarla, kendine özgü bir eğitim ve formasyon gerektiren sınıf öğretmeni de olmuşlardır.

Peki, felsefe öğretmeni olmak ne demektir, nasıl bir anlam ifade eder? Kant'a göre bunun anlamı, "bilgelik sevgisinin öğretmeni" olmaktır (Kant, 118). Bu ise bir takım bilgilerin aracılığını yapmaktan ve öğretmekten daha 
öte bir şeydir. Bilme, sorma, öğrenme, kuşku duyma, eleştirme, merak etme ve hayrete düşme yönünde bir eğilim oluşturmak, felsefeyi kendi hayatında hissedebilme duygusunu geliştirmektir. $\mathrm{Bu}$ anlamda, "Felsefe öğretimi, öğrencilere bir öğretiyi telkin etmez, onları kabul görmüş yargıları sorgulama ve onlardan kuşku duyma konusunda cesaretlendirir. Bu nedenle yerleşik anlayışa bir karşı çıkıştır. Felsefe öğretimi, sahip olunan görüşleri olduğu yerde bırakmak olsaydı, yeni hiçbir şey öğretilmiş olmazdı" (Noonan, 107). Dolayısıyla, felsefe eğitimi, değiştiren ve geliştiren bir etkinliktir. En önemli özelliği, öğrenciye, en siradan yargılar konusunda bile eleştirme, kuşku ile bakma alışkanlığı kazandırmasıdır. Bütün bunlardan felsefenin, toplum içinde yapılacak, şu ya da bu şekilde icra edilecek bir meslek olmadığını, bu da, bu öğrenimi gören kişilerin ciddi bir istihdam sorunuyla karşı karşıya oldukları anlamına gelir. Felsefenin bir iş ve istihdam alanı olarak görülmesinin haklı gerekçeleri olabilir. Bu bölümde okuyan öğrenciler, aldıkları eğitimin, kendilerine yaşamlarını sürdürebilecek bir iş ve istihdam alanı sunmasını bekliyor olabilirler $\mathrm{Ne}$ var ki, felsefe, gündelik hayatta doğrudan karşıllı̆ı olmayan bir alan olduğundan, bu eğitimi alan kişiler, mezun olduktan sonra ciddi bir istihdam sorunuyla karşılaşmaktadırlar. Bir zamanlar üniversite adaylarına yönelik hazırlanan kılavuzlarda, felsefe bölümü mezunlarının, gazetecilik ve öğretmenlik gibi mesleklerde çalışabileceklerinden söz edilmekteydi. Ancak, gazeteci olmanın felsefe bölümü mezunu olmak gibi bir koşulu yoktur. Bu işi, ilgisi ve yeteneği olan herhangi bir kişi de, felsefe eğitimi almış kişiler kadar, hatta onlardan daha iyi yapabilirler. Felsefe eğitimi almanın onlara bu alanda bir ayrıcalık kazandıracağını düşünmek yanıltıcı olabilir. Öğretmenliğe gelince, geçmiş yıllarda liselerde felsefe derslerine meslekten olmayan kişilerin de girdiği gözlenmiştir (Tozlu, 187). $\mathrm{Bu}$ da, felsefe öğretmenine ihtiyaç duyulmasına karşın, bu alanda yeterince felsefe öğretmeninin istihdam edilmediği, buna karşın, yine geçmiş yıllarda, bu alanda yetişmiş kişilerin sınıf öğretmenliği gibi, kendine özgü bilgi, beceri ve formasyon isteyen bir alanda istihdam edildikleri görülmüştür. Felsefe bölümü mezunu olan bazı kişilerin, gazetelerin okuyucu köşelerine yazdıkları mektuplarda, Milli Eğitim Bakanlığından kendilerine rehber öğretmenliğin bari verilmesini istediklerine tanık olmaktayız. ${ }^{1} \mathrm{Bu}$ durumda, felsefe eğitimi almış olan kişilerin çalışabilecekleri işler, genellikle eğitimini almadıkları alanlardan oluşmaktadır. Bunlar arasında, sınıf öğretmenliği, gazetecilik gibi alanlar da vardır. İş hayatına atılanlar, sözgelimi "İdea Lokantası" gibi bir işyeri açanlar da vardır. Bu konuda, gerek devlet, gerekse birey düzeyinde, bir plansızlığın, amaçsızlığın ve gelişigüzelliğin olduğu görülmektedir. $\mathrm{Bu}$ bölümleri tercih eden öğrenciler tercih nedenleri ve mezun olduklarında yapacakları iş konusunda açık bir görüşe sahip değillerdir. Milli Eğitim

\footnotetext{
${ }^{1} \mathrm{Bu}$ istek, 14 Eylül 2001 tarihli bir gazetenin Okuyucu Köşesi’nde yayınlanan bir mektupta dile getirilmektedir.
} 
Bakanlığı da, felsefe derslerine farklı branşlardan öğretmenlerin girmesine izin verirken ve felsefe bölümü mezunlarını sınıf öğretmeni olarak atarken, aynı plansızlığın belirtilerini gösterir. Bütün bunlar göstermektedir ki, felsefe eğitimi temel bir meslek eğitimi olarak alındığında ortaya önemli bir sorun, işsizlik sorunu çıkmaktadır. Sorunun çözümüne yönelik çeşitli öneriler yapılabilir. Bunlardan biri de şu olabilir: Felsefe eğitiminin bir meslek eğitimi olarak değil, bir meslek eğitimi ile birlikte verilmesi, olumlu ve yapıc1 katkılar sunabilir. Bunlardan felsefeye en yakın olanı, filoloji eğitimidir. Filoloji destekli felsefe eğitimi, hem felsefi metinlere ulaşma, okuyup anlama açısından (bu felsefe eğitiminin hermeneutik bir etkinlik oluşunun da gereğidir), hem de sunacağı farklı iş imkânları açısından felsefe bölümü mezunlarının önünde yeni ufuklar açabilir.

Husserl, felsefe yapmak isteyenlere kendi gözlerini kullanmalarını salık verir. Felsefenin ilk hareketi ve fişkırma noktası, kişinin kendi gözü ile görmeyi öğrenmesi, kendi aklı ile düşünmeyi başarabilmesi, bu konuda bir bebeğin emekleme, ayakta durma ve nihayet yürüme alıştırmaları gibi kendi gözleri ile görebilmeyi geliştirmesidir. Felsefe hep kendi gözünü kullanan topraklarda bol, bereketli ve ölümsüz ürünler vermiştir. Theoria, felsefenin kendini üretiş biçimi olarak bir başkasının benim yerime görmesini değil, bizzat benim kendi yerime görmemi ve varlı̆̆ kendi gözlerimle seyretmemi salık verir. İnsanlar iyi, güzel, doğru, vb. kavramlar üzerinde durup düşünmeye başladıklarında, bunlardaki özü kendi gözleri ile seyretmeye koyulduklarında felsefe de başlamıştır. Bu "durup düşünme", irdeleyen, sorgulayan, mantıklı ve tutarlı olmay1 ilke edinen sistematik bir düşünce biçimi anlamına gelir. Öyle ki, bu, bir şey söylemekten ziyade, söyleyeceğimiz söze doğru adım adım ilerlemeyi, bir şey söylemek için çok şey söylemeyi ifade eder. Bir şey söylemek, bir sıçramada bulunmaktır. Ama felsefe sıçraya sıçraya ilerlemeyi değil, adım adım yürümeyi öğretir. Adım adım sormayı, adım adım düşünmeyi, adım adım susmayı, adım adım cevaplamayı, kısaca söyleyeceğimiz söze doğru adım adım yolculuğu önerir. $\mathrm{Bu}$ nedenle "acele işi olanların" uğraşabileceği bir alan da değildir. Felsefe, dar zamanları değil, geniş zamanları seven bir etkinliktir. Çünkü ulaşmak ve orada durup kalmak istediği sabit bir hedef yoktur. Her sonuç, daha ileriye gidebilmesi için bir duraktır. Felsefe sevgisi, bir durakta kalmayı değil, sürekli yolda olmayı gerektirir. Bu anlamda felsefe bir şey söylemek, bir iddiada bulunmaktan çok, denebilirse, söylediğimiz şeyi ne kadar söylediğimizin hesabını vermek, yoldaki yürüyüşe ilişkin rapor sunmak, söylediğimiz şeyi nasıl söylediğimizin öyküsünü anlatmaktır. Bunu gerçekleştirebilen insan, kendi gözünü kullanabilen insandır. Kendi gözünü kullanmak, durup düşünmenin, şeylerin özünü aklın gözü ile seyretmenin ön koşuludur. Felsefe başkasının gözü ile yol yürümez. Tıpkı "Başkasının aklıyla dokuz adım gidilir", "Taşıma suyla değirmen dönmez" diyen atasözlerinde olduğu gibi. Şu halde felsefe eğitiminin öncelikli amacı 
insanlara bir gözlük ve görüş açısı sunmak değil, kendi gözlerini kullanabilmelerini öğretmek, görme yetilerini aktif hale getirmek, kendi açılarını bulmalarına katkı sağlamak olabilir.

Kendi gözümü nasıl kullanabilirim? Ne yaparsam, nasıl yaparsam kendi gözümü kullanmış olurum? Bu sorulara pek çok yoldan gidilebilir, pek çok yoldan cevap verilebilir. Ama hepsinden önce şu söylenebilir: Kendi sorumu sormadan ve kendi dilimi kullanmadan kendi gözlerimi kullanmış sayılmam. Eğer bir felsefe üreticisi olacaksam, bunu ancak kendi sorduğum veya kendi varlığımda konumlanmış bir soru üzerinde, kendi dilimde düşünerek gerçekleştirebilirim. Diğer diller, onları bilsem bile, bana yabancıdırlar. Benim dünyam, felsefe yaparken yürüyecek olduğum kendi yolum, kendi dilimin içindedir. Ancak kendi dilimi kullanarak kendi yolumda yürümüş ve kendi gözlerimi kullanmış olurum. Kendi dilimi kullanmam, kendi gözlerimi kullanmamın da koşuludur. Gözlerim ancak kendi sorumu sorduğumda açılır, kendi dilimi kullanmaya başladığımda görmeye başlar, aklım ancak onunla düşünebildiğim zaman benim olur. Kendilerini hangi dilden okursak okuyalım, Platon hep Grekçe, Kant hep Almanca, Russell hep İngilizce konuşur. Düşünce dünyalarının oluşumunda, konuştukları, düşündükleri ve yazdıkları dilin, sordukları sorularda içinde yaşadıkları toplumun tarihsel, kültürel, ekonomik ve siyasi koşullarının inkâr edilemez etkileri vardır. Bir bakıma hep kendi dilleri ile görürler dünyayı, varlığı, varlığın anlamını. Dili bile kendi dilleri ile görürler. Bunun haklı gerekçeleri vardır: Dil düşüncenin, duygunun ve sezginin de evidir. Bir kişi en iyi kendi dilinde düşünebilir, kendi dilinde sezebilir, kendi dilinde konuşabilir, kendi dilinde ifade edebilir. Kısaca, varlığı en iyi kendi dilinde görebilir. Kendi gözleri ile görmeye başlamak, kendi dilini kullanmakla başlar. Çözmek istedikleri sorunlar uydurma sorunlar değil, öncelikle kendi dünyalarından türeyen, bu dünyada dilsel, tarihsel ve kültürel karşılığı olan gerçek sorunlardır. Kendi gözümü kullanmanın en önemli koşulu, kendi sorumu sormam ve kendi dilimde cevap vermemdir.

Eğer felsefe yapmak, felsefi yaşantıya sahip olmak, kendi gözü ile görmeyi öğrenmekse, o zaman filozoflar neden hep başkalarının görüşleri ile ilişki içindedirler? Bunu, kendi sözlerini söyleyebilmek, kendi görüşlerine ulaşabilmek, kendi gözleri ile görebilmek için yaparlar. Onların ayrıldıkları nokta yürüdükleri yolda veya yolculukta değil, söyledikleri temel tezdedir. $\mathrm{Bu}$ temel tez de kendi gözünü kullanmanın bir ifadesidir. Kuşkusuz bu bakışı gerçekleştirmek için çeşitli gözlükler kullanabiliriz, bilim gibi, sanat gibi, eleştiri gibi. Ama taassup sahibi olmak, tek bir açıdan bakmayı mutlaklaştırmak, farklı görüş ve yaklaşımlara hoşgörüsüz davranmak gibi yönlendirilmiş bir gözle asla bakamayız. Bu, teheoriayı (nazar, seyir, temaşa, contemplation) öldüren bir yaklaşım olur. Kendi gözünü kullanmayı yalnızca felsefecilere ve felsefe yapmak isteyenlere değil, yeryüzünde kendi 
varlı̆̆ını hissetmek isteyen herkese tavsiye edebiliriz. Ancak kendi gözleriyle görebilenler, kedi akıllarıyla düşünebilenler, kendi yürekleri ile hissedebilenler "gerçekten yaşadım, gerçekten varoldum" diyebilirler. Kendi gözünü kullanmayı, yaşam karşısında bir tutum olarak benimsemek gerekir. Kendi gözlerimle görmeyi önemsemeliyim. Çünkü başkasının gözü benim yerime görmez, ben ancak kendi yerime görebilirim. Başkasının bakışı beni gören kişi yapmaz. Başkasının sesi beni ifade etmez. Filozof, kendi gözleri ile bakan, kendi gözleri ile gören, kendi aklı ile düşünen kişidir. Felsefe eğitimi, kendi gözü ile görebilmenin, kendi aklıyla düşünebilmenin eğitimidir. Ama bu hep başka bakış ve görüşlerle ilişki içinde ortaya çıkar. Felsefe eğitimi bu iletişimi ve diyaloğu sağlayan bir eğitimdir.

Kendi gözü ile görmeye, kendi dili ile konuşmaya, kendi aklı ile anlamaya başlamak, hermeneutik bir süreçtir. Bu eğitim sürecinde, kişinin varlığa, varlığın anlamına ilişkin düşünce ve tecrübeleri de olgunlaşır. Kendi anlamasını gerçekleştirmek, kendi bakış açısını bulmak ve kendi hermeneutik dairesi içinde kendi yorumunu yapmak için bu eğitim sürecine gereksinim duyar. Felsefeyi yaşantı haline getirmek, yalnız kendi bakışını gerçekleştirmek, kendi aklını kullanmakla gerçekleşmez, daha önceki bakış ve görüşleri de gerektirir. Bu nedenle felsefe öğrencisi, öncelikle filozofları anlayan, onlarla diyalog içine giren, onları dinleyen ve kendisi de konuşmaya çalişan bir kişidir. $\mathrm{Bu}$ diyalog, onların özgür ve özgün yorumlarını da getirir.

\section{SONUÇ}

Hayatımızda felsefenin, felsefi soruların parlayıp söndüğü anlar vardır. Gündelik yaşam, kendi hızlı akışı işçinde sürekli olarak bu öğeleri dışarı atma veya belirsiz hale getirme eğilimi taşır. Felsefe eğitimi, her şeyden önce bu yaşantılara sahip çıkma, onları çoğaltma ve sürekli kılma girişimidir. Bu haliyle yaşam boyu süren, kişinin formal ve informal bütün deneyimlerini içeren bir eğitim biçimidir. Mesleki bir öğretim programı olarak alındığında, gündelik yaşamda doğrudan bir karşılığı ve işlevi yoktur. $\mathrm{Bu}$ eğitim biçiminde kişinin kendi kendisini eğitmesi, kendi kendisinin öğretmeni olması esastır. $\mathrm{Bu}$ da, kendi yeteneğini işlemekle, kendi potansiyelini aktif hale getirmekle, hayret ve merak duygusunu harekete geçirmekle, soru sorma, yanıt verme, tutarlı, ayrıntılı ve kavramsal bir biçimde düşünme becerisi kazanmakla, bu şekilde felsefi bir yaşantı içine girmekle gerçekleşebilir. Bu nedenle felsefe eğitimi, bir mesleğin bilgisini ve pratiğini kazanmayı değil, daha çok bir yaşantı içine girmeyi hedefler. Nusret Hızır, "Felsefe Kant'ın, Comte'un ne dediği değildir. Felsefenin ne olduğunu iyice anlamak, ne yaptığını saptamak olmalıdır felsefe eğitiminin amacı" dedikten sonra şunları ekler: "Otorite olarak değil, dostça bir öğüt vermem gerekirse, ögüdüm, yalnızca 'içtenlik'tir” (Hızır, 17, 25). Felsefe eğitimi böyle bir içtenliğe yönelmelidir. İçtenlik, felsefenin kendi 
varoluşumuzda bir karşılık bulması ve yaşantımız içinde bir konum kazanmasıyla ortaya çıkabilir. Bu karşılık oluştuğunda, felsefe de, felsefe eğitimi de içtenlikli hale gelir. Bir yaşama sanatı olarak felsefe, böyle bir içtenlik alanında ortaya çıkar. Bir gösteri, bir nümayiş ve demagoji aracı haline geldiğinde, sağlıklı gelişsimini kaybeder. İçtenlik alanında konumlanan felsefenin doğasında, hocalıktan çok öğrencilik vardır. Yolu ve yolculuğu bitiren bir hocalık, felsefeyi de bitirmiş olacaktır. Felsefenin insana öğretebileceği bir hakikat varsa, onu, her şeyden önce, kendi deneyimi ve çabası ile kazanması gerekir. Felsefe, ancak kendisinden sonra gelen bir şey için öğrenilir. $\mathrm{Bu}$ da, bir meslek değil, yine felsefenin kendisidir. Felsefe eğitimi, döngüsel bir etkinliktir, öncelikle kendisi için, felsefe yapmak için öğrenilir. 


\section{KAYNAKLAR}

Aristoteles. (1985). Metafizik (Çev. Ahmet Arslan). İzmir: Ege Üniversitesi Edebiyat Fakültesi Yayınları.

Camus, A. (1988). Sisyphos Söyleni (Çev. Tahsin Yücel). İstanbul: Adam Yayınları.

Dewey, J. (1961). Democracy and Education. An Introduction to the Philosophy of Education. New York: The Macmillan Company.

Hızır, N. (1985). Bilimin Işı̆̆ı̆ıda Felsefe. İstanbul: Adam Yayınları.

Husserl, E. (1995). Kesin Bir Bilim Olarak Felsefe (Çev. Tomris Mengüşoğlu). İstanbul: YKY

İnam, A. (1994). "Felsefede Deneme Yazmak." Felsefe Dünyast, 12.

Jaspers, K. (1986). Felsefe Nedir? (Çev. İ. Zeki Eyüboğlu). İstanbul: Say Yayınlar1.

Kant, I. (1980). Pratik Aklın Eleştirisi (Çev. İ. Kuçuradi, Ü. Gökberk, F. Akatl1). Ankara: Hacettepe Üniversitesi Yayınları.

Noonan, J. (1997). "Philosophy in a Fragmented World." International Studies in Philosophy 29: 1, 99-109.

Reid, L. A. (1968). Philosophy and Education: An Introduction. London: Heinemann Press.

Rusk, R. R. - Scotland, J. (1981). Doctiriens of the Great Educators. Bristol: The Macmillan Press.

Tozlu, N. (1992). "Liselerde Felsefe Dersinin Öğretiminde Karşılaşılan Problemler.” Ĕgitim Problemlerimiz Üzerine Düşünceler'de. Van: Yüzüncü Y1l Üniversitesi Fen-Edebiyat Fakültesi Yayınları.

Wittgenstein, L. (2003). Tractatus (Çev. Oruç Arıba). İstanbul: Yapı Kredi Yayınları.

Wittgenstein, L. (1998). Felsefi Soruşturmalar (Çev. Deniz Kanıt). İstanbul: Küyerel Yayınları 